\title{
Kísérleti orvostudománytól a rendészettudományig
}

\section{Interjú Haller József egyetemi tanárral, az MTA doktorával ${ }^{1}$}

\begin{abstract}
Neurobiológus, kutató, 2004 óta a Magyar Tudományos Akadémia doktora. Szakterülete a magatartás-neurobiológia és kriminálpszichológia. 1999 és 2019 között a Kísérleti Orvostudományi Kutatóintézet Viselkedés Neurobiológia osztályának vezetője volt, ahol 2016 és 2019 között a Viselkedésvizsgáló Egységet is vezette. Rendszeres oktatói tevékenységet folytatott az Eötvös Loránd Tudományegyetemen, a Szent István és Pázmány Péter Katolikus Egyetemen, valamint a Semmelweis Egyetem doktori iskolájában. Tanszékvezetô a Nemzetközi Közszolgálati Egyetem Kriminálpszichológiai Tanszékén. Kutatási területe az agresszivitás, a drogok (kannabinoidok), a szorongás és a poszttraumásstressz-zavar viselkedési és neurobiológiai aspektusai. Két magyar és két angol nyelvű tudományos szakkönyv szerzője, valamint írt másfél tucat könyvfejezetet. Különböző nemzetközi folyóiratokban 158 tanulmánya jelent meg, több, amelyre 6212 független hivatkozás érkezett. A tudományos teljesítmény mérésére használt Hirsch-indexe 49. Számos konferenciát szervezett, illetve több hazai és nemzetközi tudományos folyóirat szerkesztőségének volt, vagy jelenleg is tagja. A Drogkutató Intézet igazgatójaként a tudományos kutatómunkák vezetője, az Interdiszciplináris Drogszemle szerkesztőbizottságának elnöke. Új feladata 2021-től a Nemzeti Közszolgálati Egyetem Rendészettudományi Doktori Iskolájának a vezetése.
\end{abstract}

Kriminálpszichológia tantárgyat már a Rendészettudományi Kar jogelődjén a Rendőrtiszti Főiskolán, annak megalakulásától kezdve oktatunk; tanáraink között olyan illusztris személyiségek voltak, mint Popper Péter. Az első kriminálpszichológia oktatására specializált szervezeti egység 2015 szeptemberében alakult meg, a Rendészeti Magatartástudományi Intézet keretein belül működő Kriminálpszichológiai Tanszék. Az intézet Dr. Hegedűs Judit PhD, a tanszék Fogarasi Mihály PhD. mb. tanszékvezető irányításával kezdte meg munkáját. 2016 januárjában Dr. Haller József PhD lett az intézet, majd 2016 nyarától a tanszék vezetője. 2019-ben az intézet megszűnt, a Kriminálpszichológia Tanszék azóta önálló oktatási egységként múködik tovább. A tanszék oktatási profilja az általános pszichológiai ismeretek közvetítésétől, a kriminálpszichológiai ismereteken át a bünügyek kriminálpszichiátriai elemzéséig terjed.

Az interjút készítette Kontráné Lovas Petra és Németh Zsolt, a Magyar Rendészet szerkesztőségének munkatársai, közreműködött Major Marcell hallgató, az RTK Magánbiztonsági és Önkormányzati Rendészeti Tanszék demonstrátora. 
Magyar Rendészet: Professzor úr, Ön egy nemzetközi tudománymetriai felmérés szerint a Nemzeti Közszolgálati Egyetem oktatói közül egyedüliként, 198 magyar kutató társaságában a világ tudományos gondolkodására leginkább ható tudósok sorába tartozik. Miról van szó pontosan?

Haller József: A tanulmány a PLOS Biology nemzetközi tudományos folyóiratban jelent meg, négy tudománymetriával foglalkozó szerző írta. Egy általuk kidolgozott szempontrendszer szerint a világ nagyjából hétmillió tudósa közül összeállították annak a százezernek a listáját, akik szerintük a legnagyobb mértékben járultak hozzá a tudományos gondolkodás fejlődéséhez. Nem voltak szakterületi vagy másfajta „kvóták”; egyedül a tudósok munkásságának úgynevezett tudományos impaktja számított. Hat szempont szerint értékeltek; ezek egyike a múvekre érkezett hivatkozások száma, a másik fontos mérőszám pedig a Hirsch-index volt, amely lényegét tekintve a kitartó kiválóság mérőszáma. A további négy mérőszám azt volt hivatott felmérni, hogy milyen fontos szerepet töltött be a vizsgált személy a tudományos múvek létrehozásában. A listán valóban 199 magyar kutató szerepelt, de ez a szám némi felülbírálatra szorul, mert a 199 magyar illetőségűnek feltüntetett szerző egyikének-másikának nem sok köze volt Magyarországhoz, míg a nem magyarnak feltüntetett szerzők egy része viszont Magyarországon fejtette ki tudományos tevékenységének zömét, és jelenleg is magyar állampolgár. A szerzők csaknem hétmillió szerző adatait dolgozták fel, és ennél a mennyiségnél még a mai technikai feltételek mellett is előfordulnak hibák. Egyébként hízelgő, hogy a kutatók felső fél százalékába kerültem, de nem szabad eltúlozni a dolog jelentőségét. Ha egyébért nem, akkor már csak azért sem, mert a hivatkozási listák csak 1995 óta teljes körűek, és csak nemzetközi publikációkat vettek figyelembe, így azok, akik ennél lényegesen korábban vagy anyanyelvükön írták meg fő múveiket, hátrányból indultak. A lista a 2018. évi állapotot tükrözte 1995-2017 közötti hivatkozások alapján, számtalan kiváló kutatóval azok között, akik felkerültek rá, és számtalan kiváló kutatóval azok között, akik nem.

\section{M.R.: Értesítették az előkelő helyezésről?}

H.J.: Nem, természetesen senkit sem értesítettek külön. Egy doktorandusztanítványom jelezte, hogy megjelentem ezen a listán, és - utólag is elnézést kérve érte - első pillanatban meg is sértődtem, hogy csak a harmincezredik hely környékén vagyok. Később persze átgondoltam, hogy egy csaknem hétmillió kutatóból álló populációban ez nem túl rossz hely, végül is bekerültem a felső fél százalékba.

\section{R.: Önt milyen tudományterületen vették figyelembe?}

H.J.: Mindenkinél három tudományterületet neveztek meg. Az én esetemben az első a „neurológia, neurobiológia” volt, amit Magyarországon „idegtudományként” tartunk számon. A második tudományág, ahova besoroltak a viselkedéstudomány volt, 
míg a harmadik az összehasonlító pszichológia. Manapság a tudományban minden interdiszciplináris, ezért egyetlen tudományterület sem fedi le valakinek a teljes munkásságát. Valószínúleg ezért soroltak be mindenkit háromféleképpen. Szerintem az, hogy a neurológiát és a neurobiológiát összevonták egy kicsit fura, mert neurológiával soha nem foglalkoztam, de mindegy, alapvetően jól lőttek be. Úgy tekintették, hogy idegtudományi alapú viselkedéstudománnyal foglalkoztam, ami összehasonlító pszichológiának is tekinthető.

\section{R.: Lehet tudni, hogy mely munkái lettek alapul véve?}

H.J.: A felmérés átfogó volt. Nem egyes publikációkat vettek figyelembe, hanem az összes munkát, amely egy adott szerzőhöz köthető. Ennek alapja az a nyilvántartás, amelyet az Institute for Scientific Information (ISI) tart karban, és amely, mint mondtam, 1995-től kezdve teljes körű, legalábbis annak a körülbelül 15 ezer nemzetközi folyóiratnak a tekintetében, amelyet az intézet nyomon követ. Jelentős részben ebből az adatbázisból táplálkozik a Magyar Tudományos Múvek Tára (MTMT) is, azzal a kiegészítéssel, hogy az MTMT-ben magyar nyelvű publikációk is helyet kapnak, míg az ISI csak nemzetközi publikációkat vesz figyelembe.

\section{M.R.: Az ember génszerkezetéról egyre többet tudunk, a gének mennyiben határozzák meg az ember viselkedését?}

H.J.: Ez a tudomány kiemelt jelentőségű az emberi vagy éppen állati viselkedés meghatározó tényezői között, sőt, a „genetikai érv” a bíróságokon is felmerül, elsősorban az Egyesült Államokban, de néhány európai országban is. Sokan gondolják ugyanis azt, hogy a törvényszegő viselkedés, például az erőszakos bűntettek - amúgy részleges - genetikai meghatározottsága csökkenti az elkövető felelősségét. Manapság nem túlságosan bonyolult, és nem is kivételesen költséges felmérni valakinek a genetikai hátterét, és ha „hibás” génre akadnak, azt az ügyvédek felhasználhatják a tárgyaláson. Eléggé sok olyan gént ismerünk, amely összefügg az agresszióval és az erőszakossággal, és ezt lehet felelősséget korlátozó tényezőként is prezentálni. Az utolsó cikk, amit erről olvastam 81 olyan amerikai pert tekintett át, amelyben a „genetikai érv" befolyással volt a bíróra, illetve a kiszabott büntetés mértékére. Egyébként nemcsak a genetika lett része bírósági érvrendszernek, hanem a neurobiológia is. Sőt a „neurobiológiai érv” talán fajsúlyosabb is, mint a genetikai. Talán ezért jött létre az elmúlt két évtizedben a „neurolaw”, amit idegtudományi törvénykezésként fordíthatnánk le magyarra. Az Egyesült Államokban egy ideje már bírókat, ügyészeket és ügyvédeket oktatnak „neurolaw”-ra, mert a bíróságokon egyre gyakrabban vetődik fel ez a kérdés, mint felelősséget csökkentő tényező. 
M. R.: Most nagyon a közepében vagyunk a dolognak, ugye ez az, amit a köznyelv háborogva mond: majd biztos jönnek a szakértők, és nem lesz megbüntetve a brutális gonosztevő.

H.J.: A szakértők nem hoznak ítéleteket. Az ítéletet a bíró hozza, azoknak az ismereteknek a birtokában, amelyekkel rendelkezik. Pontosan azért oktatják a bírókat neurobiológiára, hogy kompetens döntést tudjanak hozni. Nem az a cél, hogy bárki számára mentességet kreáljanak, hanem az, hogy olyan ítéletek szülessenek, amelyek figyelembe veszik a tudományos haladás vívmányait. Ez nemcsak és nem elsősorban a vádlott érdekeit szolgálja, hanem inkább a társadalom egészének érdekeit. Egyébként a genetikai vagy éppen neurobiológiai érv nem csökkenti feltétlenül az elkövető felelősségét. Egy génvariáns, vagy éppen egy agyszerkezeti vagy agyműködési sajátosság összefüggésbe hozható lehet valamilyen bủntettel, de egyúttal az is kiderülhet, és gyakran ki is derül a szakértői véleményekből, hogy ez nem kényszerítő erejű a tett elkövetésének szempontjából.

\section{M.R.: És Magyarországon mennyire van ennek gyakorlata?}

H.J.: Nem ismerem a hazai joggyakorlatot eléggé ahhoz, hogy erről kompetens véleményt mondjak. Az viszont tény, hogy jónéhány évvel ezelőtt engem is felkértek egy neurobiológiai szakvélemény megfogalmazására, amit meg is tettem, és amennyire tudom, a bíróság figyelembe is vette a szakvéleményt. Persze furcsának tủnhet, hogy az amerikai joggyakorlatot jobban ismerem, mint a magyart, amire egyetlen magyarázat van: az Egyesült Államokban nagy súlyt helyeznek a tudományos publikációkra, ezért könnyú tájékozódni.

\section{M.R.: Van ennek a tudásnak létjogosultsága a Rendészettudományi Karon?}

H.J.: Abszolút. Ez nemzetközileg igen fontos kérdés, mivel az elkövetői felelősséget érinti. Sok kutatási eredményt publikáltak a témában, és sok könyvet is írtak róla. Ezek többségét természetesen olvastam. Bár szorosan véve nem az én szakmám, de közvetve kapcsolódik ahhoz, amit jómagam oktatok vagy éppen kutatok.

\section{R.: A Rendészettudományi Karnak akkor azt kell tanítania, hogy az az el- követő, akinek az agyszerkezete rendben van, az felelös a cselekményéért, azt meg kell gyanúsítani?}

H.J.: A dolog ennél jóval bonyolultabb, mert az összefüggés nem egyenes. Hogy egy példát mondjak, az erőszakos bűnözők homloklebenye kisebb az átlagnál. Kissé sommásan elmagyarázva a felismerés jelentőségét: a homloklebeny az „agy agya”, ott van elrejtve egyéniségünk, erkölcsi normáink és empátiánk. A homloklebeny térfogata, sejtsűrűsége, kérgének vastagsága stb. egyéni varianciát mutat, más szóval ebből 
a szempontból (sem) vagyunk egyformák. Ennek számtalan oka van, kezdve a genetikai tényezőktől a kora gyerekkori traumákig. Vannak olyanok, akiknek viszonylag kis homloklebenye van, és sohasem követnek el bűntetteket, és vannak olyanok is, akiknek viszonylag nagy homloklebenye van, és mégis bűnözők. A homloklebeny és az erőszakosság közötti viszony ugyanis statisztikai: igaz az átlagra, ennélfogva az esetek többségére, de nem mindenkire. Amíg a bűnözői hajlam különböző tényezőinek hálózatát - amelyben a homloklebeny csak egyetlen hálózati pont - fel nem derítjük, a fenti felismerésnek inkább alapkutatási, semmint gyakorlati jelentősége van. Érdemes tudni róla, de nem lehet valakit gyanúval kezelni pusztán a homloklebeny térfogata miatt. Egyébként ismételten megjegyzem, hogy a szakértő nem hoz döntéseket, nem fogalmaz meg ítéleteket, csak ismereteket hoz létre, vagy éppen népszerűsít. Az új ismereteket a jog építi bele saját normáinak épületébe.

\section{M.R.: A büntető igazságszolgáltatás gyakorlatában néhány évtizede a treat- ment ideológia jelentős teret kapott, miszerint a búntettest nem büntetni kell, hanem kezelni.}

H.J.: Ez a trend nem annyira új, mint sokan gondolják. Valójában a '60-as, '70-es években csúcsosodott ki, amikor (legalábbis az Egyesült Államokban) több embert ítéltek kényszerkezelésre, mint börtönbüntetésre. A vonatkozó kutatási eredmények szerint ez valamikor a 2000-es évek tájékán fordult meg annyira, hogy manapság ritka, hogy valakit börtön helyett kórházba küldjenek. E miatt több publikációban sajnálkoztak különböző szerzők. A bűnözői felelősség kérdésében - általában véve - négy lehetséges álláspont körvonalazódik. A hagyományos álláspont szerint, aki bűnt követ el, bűnhődjön, ha tudatában volt annak, hogy mit tesz, és ha tudta, hogy az bűn. A biologizáló álláspont lényegében azt állítja, amit felvetésében megfogalmazott, nevezetesen azt, hogy az elkövető sokszor inkább beteg, semmint bưnöző, és ezért gyógyítani kell. Itt megemlítem Adrian Raine-t, aki nagyjából 30 éve írt könyvet a kérdésről, amelynek továbbfejlesztett változatait azóta többször kiadták. Ő volt egyébként az, aki először mutatta ki, hogy az erőszakos bűnözők homloklebenyével bajok vannak. A szociologizáló álláspont szerint a bűntettért nem az elkövető, hanem a társadalom a bűnös, ezért a társadalmat kell mielőbb „meggyógyítani”. Végül a haszonelvú álláspont szerint mindegy, hogy ki a bünös, a lényeg, hogy a bủntettet ne kövessék el újra, ezért a bűnözőt ki kell zárni a társadalomból. Mind a négy álláspont mellett szólnak elfogadható érvek, és mind a négyet kétségbe lehet vonni ugyanolyan mértékben elfogadható érvek alapján. Egy futó példát kiemelve: tanulmányok ezrei bizonyítják, hogy a társadalom jelentős mértékben hozzájárul a „bűnöző elme” létrejöttéhez. Ugyanakkor eléggé naivnak tűnik az, aki arra számít, hogy a társadalmat záros határidőn belül „meggyógyíthatjuk” - hiszen ezzel jónéhány évezrede próbálkozunk, és eddig nem sikerült. Ismételten fel kell egyébként hívnom a figyelmet arra, hogy a tudomány csak közvetve társadalomformáló erő. A tudomány ismeretekkel szolgál, amelyek legfeljebb fogódzókat szolgáltatnak a különböző kérdésekben. Azt is meg 
kell jegyeznem, hogy a „bűn és bűnhődés” témájában még sok a tisztázandó kérdés. Azt mondanám, hogy jelenleg az igazság mozaikdarabkáit tártuk fel. Ezek szerint valóban vannak, akik a gyógyításra és nem a büntetésre szolgáltak rá, és vannak olyanok is, akik esetében a gyógyítás kérdése fel sem merül. A két szélsőség között azonban számtalan köztes eset van, a határvonalat pedig jelenleg nehéz meghúzni. Egyébként megkérdezném: biztos, hogy a biológiai tényezők egyben felmentő tényezők is?

\section{M.R.: Éppen ezt akartuk kérdezni.}

H.J.: Ezt a hallgatóknak a következőképpen szoktam elmagyarázni. Mozart hatévesen írta az első zenemúvét, 14 évesen operát írt, ami egyike a legbonyolultabb zenei műveknek, és egy alkalommal, amikor Bécsben felejtette a partitúrát, Salzburgban három nap alatt írt egy másik zenemúvet, hogy ne kelljen Bécsbe visszaszekereznie. Emellett két hangszeren virtuóz volt, és néhány továbbin jól játszott. Ezt genetikai háttér nélkül nem lehet megtenni. Zseninek születik az ember, nem tanulja. Hozzátenném, hogy zeneszerző családban nőtt fel, és apja ugyanúgy támogatta, mint a társadalom. Kisgyerekként például nagy sikerű koncerteket adott a császári udvarban. Teljesítménye tehát biológiai, családi és társadalmi tényezőknek egyaránt tulajdonítható. Megvonjuk ezért elismerésünket tőle, mondván, hogy nem magának, hanem génjeinek, és a társadalomnak köszönhette teljesítményét? Most fordítsuk ezt meg, és képzeljük el, hogy valaki „rossz génekkel” születik, rossz családban nő fel, és a társadalom kiveti magából. Megtehetjük, hogy a körülmények miatt felmentjük tetteinek következményei alól, de akkor Mozartot se „dicsérjük meg”. Genetika, otthoni környezet, társadalom: az egyiknek minden a kezére játszott, a másiknak minden „keresztbe tett”. Milyen jogon hódolunk az egyiknek, ha a másikat felmentjük? Leginkább azért, mert egyik körülmény sem kényszerítő erejü. Ahogy Mozart nem ítéltetett a sikerre, úgy a másik sem ítéltetett bűnözésre. A biológiai, családi és társadalmi tényezők esélyeket növelnek vagy csökkentenek, de nem döntenek, és nem cselekednek. Aki dönt és cselekszik, az az ember. A tényezők magyaráznak, de szélsőséges eseteket kivéve nem mentenek fel - legalábbis ez az én és sok más ember véleménye.

\section{M.R.: Most támadt egy impertinens kérdésünk, miután az ön teljesítménye nem hétköznapi, ez vajon az agyszerkezetének köszönhető, vagy mondjuk a szorgalmának?}

H.J.: Szeretnék Mozart lenni, de nem vagyok. Bár nyilván születtem némi képességgel, készségeimért meg kellett dolgoznom. Megjegyzem azonban, hogy a szorgalom képessége is öröklődik, azt tanulmányok bizonyítják. Végső soron tehát annak is vannak biológiai tényezői, amivel biológiai hiányosságomat, nevezetesen a zseniség hiányát pótolni igyekeztem... 


\section{R.: Ön tanítja a rendöröknek azt, hogy a születési helyzetük meghatározza az ember sorsát? Amit a filozófus Heller Ágnes érzékletesen így fogalmazott meg: „Születésünk véletlenje folytán valamennyien bele vagyunk hajítva a világba”. Ez így van?}

H.J.: A viselkedésünk meghatározottsága ennél sokkal bonyolultabb. Ahogy a biológia is csak néhány elemét fedi le a tényezők egy nagyon bonyolult hálózatának, a társadalmi meghatározottság is csak egy részelem. Én e bonyolultságot és a bonyolultság mögött megbúvó szabályszerűségeket igyekszem tisztázni a hallgatók előtt.

\section{M.R.: Az ön tudománya, az elöadásai mit üzennek a rendőröknek: hogyan bánjanak az elkövetővel, hogy nézzenek rá, és hogyan viszonyuljanak hozzá?}

H.J.: Az én előadásom rámutat, hogy a bűnözők nagyon sokfélék, és egyazon bűntípuson belül is sok altípus van. Az erőszakos bűnözést példának véve: van, aki az agresszióját eszközként használja céljai elérése érdekében. Nem azért erőszakos, mert dühös, hanem hogy pénzt szerezzen, vagy tekintélyt vívjon ki magának. Mások épp ellenkezőleg, képtelenek úrrá lenni a dühükön, és utólag nagyon sajnálják, ami történt. Ezek egyébként - az előzőkkel ellentétben - gyakran fordulnak orvoshoz, és nem teszik rosszul, mert ezt a fajta agressziót elég jól lehet kezelni. Végül vannak, akik tetteit irracionális gondolatok irányítják, és ezek hatására folyamodnak erőszakhoz. Pszichózis hatása alatt cselekednek, és nemcsak, hogy nem fogják fel bűnnek, amit tesznek, hanem épp ellenkezőleg, azt hiszik, hogy az erőszak a társadalom javát szolgálta. Ez az egyik dolog, amit szeretnék megértetni velük: hogy ne gondolkodjanak egyszerű kategóriákban, mert igaz, hogy aki erőszakos bűnt követ el, az erőszakos bűnöző, de a három típus között lényegbevágó különbségek vannak. A másik dolog, amit érdemes kihangsúlyozni, az, hogy a bűnözők tipizálása nem akadémikus játék. Ha tudom, hogy a bűnelkövető mit és miért tesz, azt is tudni fogom, hogy hogyan viszonyuljak hozzá. Tudom, hogy mire lehet számítani tőle, hogy hogyan ajánlatos kihallgatni stb.

\section{R.: Másképpen hogyan? Például hogy fejjel lefelé lógatjuk a plafonról vagy pedig cigarettával kínáljuk? Vagyis mi ez a másképpen kihallgatás?}

H.J.: Egy kétórás előadás és ugyanilyen hosszú gyakorlati foglalkozás anyagát nehéz dióhéjban összefoglalni. A lényeg az, hogy a „dühös” elkövetőnek bűntudata van, ami a kihallgató számára, de az elkövető számára is lehetőségeket nyit, míg az, aki az erőszakot eszközként használja, csak az érdekeit tartja szem előtt, és csak érdekei felől közelíthető meg. Végül a pszichotikus szívesen elmagyarázza, hogy mit miért tett, de - akár tetszik, akár nem - az egyetlen megoldás az orvosi kezelés. Itt a kihallgatás célja leginkább egyfajta elődiagnózis felállítása, majd orvosi segítségkérés, ha az előzetes gyanú beigazolódni látszik. Három elkövetőtípushoz háromféle kihallgatási 
stratégia társul, különböző célokkal és eszközökkel. És akkor még csak az erőszakos bủntettek elkövetőiről beszéltem.

\section{R.: Hadd pontosítsuk, azt akarja megértetni hogy a bünelkövetés az élet része, velejárója?}

H.J.: Nem, egyáltalán nem. A bűnözői karrierek tanulmányozása egyértelművé tette, hogy az emberek többsége soha nem követ el bűntettet, és a fennmaradó 20-25 százaléknak is csak igen kis hányada, a lakosságnak mindössze 2-3 százaléka „hivatásos” bűnöző. Őket soroljuk egyébként az élethosszig tartó bűnözői pályát bejárók közé.

\section{R.: Tehát akkor mégis, hogy viszonyuljon a rendör a búnelkövetőhöz?}

H.J.: Nagyon röviden és sommásan azt mondanám, hogy tudás birtokában. E tudásnak nagyon sokrétűnek kell lennie, és helyet kell kapjon benne a bűnözők ismerete is, a kriminálpszichológia. Illúzió azt képzelni, hogy minden bűnöző egyforma, és persze erős túlzás azt állítani, hogy mindegyik teljesen más. A bűnözőknek típusai vannak, bűnözésfajtánként más és más. Amit például az imént az erőszakos bűnözőkről elmondtam, teljesen másképp néz ki a szexuális bűnözők esetében, vagy egy búnszervezeten belül. Nem lehet, sőt nem is szabad mindegyik elkövetőhöz ugyanúgy viszonyulni. Nincsenek általános receptek. Receptek sokasága van, mint a konyhában. Én azokkal az ismeretekkel igyekszem felvértezni a hallgatókat, amelyeket elődök sokasága felhalmozott. Ez persze csak útravaló. Az elődök tapasztalata segít, de mindenkinek szüksége van saját tapasztalatokra is, amelyeket szakmai tevékenysége során szerez meg. Ha jó alapokkal indul - és ezen vagyunk -, akkor hamar válik profivá, ha felkészületlenül kezdi a pályát, akkor később, vagy talán soha.

\section{M.R.: A beismerő vallomás, amint tudjuk, nem feltétlenül kell, de azért az a szakmának mégis követelménye.}

H.J.: Akkor maradjunk annyiban, hogy nem a beismerő vallomás, hanem az információszerzés a fontos. Tehát az a feladat, hogy olyan információt nyerjünk, amelyet nem biztos, hogy a búnöző meg akar osztani velünk. Arra készítem a hallgatókat, hogy szakmájuk gyakorlása közben csupa olyan emberrel lesz dolguk, akik bűnt követtek el, de tudniuk kell különbséget tenni a különböző bűnelkövető típusok között. Például a szexuális bűnelkövetőknél más a teendő, mint egy drogdílernél, sőt a drog nagybani forgalmazója is teljesen más tulajdonságokkal rendelkezik, mint az egyszerü drogdíler. Tudniuk kell, hogy melyiktől mire számítsanak, amikor kapcsolatba lépnek velük. Nem az a kérdés, hogy megértik vagy elutasítják a bűnözőt, hanem az, hogy technikailag fel legyenek készülve. 


\section{R.: Jól tudjuk, a tudományos álláspont szerint, hogy az ember agyszerke- zete 20-25 éves korára szilárdul meg, és ez azt jelenti, hogy addig nem teljes a tetteiért a felelössége?}

H.J.: Pontosítanék: a homloklebeny - az „agy agya”, ahogy korábban aposztrofáltam - valóban 20-25 éves korban éri el teljes fejlettségét. Ez azonban korántsem jelenti azt, hogy az ennél fiatalabbaknak „nincs agyuk”, vagy éppen képtelen lennének felfogni azt, amit tesznek, vagy azt, ami körülöttük vagy velük történik. A fejlődés nem egy szivárvány, amely alatt egyik pillanatról a másikra átmegyünk, hanem egy folyamat. A magam részéről nem gondolom azt, hogy az ember csak a homloklebeny teljes kifejlődésének pillanatában válik felelőssé a tetteiért. Ilyen mértékig nem kapcsolnék össze egy biológiai fejlődési folyamatot egy jogi konstruktummal.

\section{R.: Az evolúciónak mi a szerepe az agyi szerkezet alakulásában?}

H.J.: Mint minden szerv, az agy is az evolúció terméke; erről így általában véve nincs különösebb mondanivalóm. Két dolgot viszont kiemelnék. Az egyik az „agresszióra termett állati agy” és a „békére predesztinált civilizáció” konfliktusa, amelyből néhányan a bűnözést is levezetik. Az efféle elméleteket néha egészen tetszetős formában fogalmazzák meg, de nem látom, hogyan lehetne ezt bizonyítani. Ez számomra megmarad az elme játékának. Egy másik dolog viszont szerintem több figyelmet érdemel, nevezetesen az agynak az a képessége, hogy fejlődése - bizonyos keretek között - módosuljon. Nagyon nyersen megfogalmazva: a korai stresszek, különösen a traumás jellegűek, az agyat egy olyan fejlődési útvonalon indítják el, amely felnőttkorban az agresszivitást favorizálja. Teoretikusan úgy is meg lehet fogalmazni a dolgot, hogy a korai nehéz életkörülmények mintegy előre jelzik a későbbi nehézségeket, és az agy ennek megfelelő fejlődési pályát jár be, mintegy felkészülve a küzdelmes életre. Ez eléggé spekulatív, az azonban kétségtelen tény, hogy a genetika mellett, ami végső soron az evolúció terméke, az életkörülmények is irányítják az agy fejlődését. Kérdés, hogy a lehetséges fejlődési variánsok programozottak vagy egyszerű károsodások. Lehet, hogy az agy fejlődését több, evolúciósan kódolt genetikai program határozza meg, és a környezeti feltételektől függ, hogy melyik lép működésbe. Ez hihetőbbé tenné az imént említett spekulációkat. Ugyanakkor az is elképzelhető, hogy a külső körülmények mintegy megzavarják az agy fejlődését, és az nem tudja befutni azt a pályát, amelyre kódolva volt. Az epigenetika jelensége, a gének születés utáni módosulása talán az előző feltételezést favorizálja, hiszen az epigenetika szabályozott folyamat. Így valóban elképzelhető, hogy több evolúciós programunk van az agyszerkezetre, amelyek között a környezet mintegy válogat.

\section{R.: A szerep, ami kialakul ennek folytán az emberben, és amelyre szüksége is van, rögződik egy életre?}


H.J.: Akár kódolt fejlődési alternatívákról van szó, akár károsodott fejlődésről, az időt nem lehet visszaforgatni. Bár az utóbbi két-három évtizedben bebizonyosodott, hogy az agyban keletkeznek új idegsejtek, ez elsősorban a memóriafolyamatokkal kapcsolatos, az agy szerkezetét nem befolyásolják lényegesen. Ugyanakkor az agy nemcsak a korai életkorokban szenvedhet el változásokat, hanem gyakorlatilag az egész élet során bármikor. Sommásan megfogalmazva: ami elromlott, az aligha javul meg később, de ami megfelelően fejlődött, azt később még el lehet rontani.

\section{M.R.: De nincs valami szerepe a civilizációnak, a társadalmi elvárásoknak abban, hogy miként viselkedünk az emberek között, még akkor is, ha van bennünk agresszív késztetés?}

H.J.: Dehogy nincs. A biológia pusztán keretrendszer. Ez azonban meghatározza azt, hogy mit építünk be tudatunkba abból, ami életünk során hat ránk. Olyan, mint egy edény: mi töltjük fel, de van egy kapacitása.

\section{M.R.: Vajon az emberiség fennmaradását a másik emberre tekintettel cse- lekvő stratégia vagy az önző magatartás biztosította-e?}

H.J.: Ha az altruizmust és az önzést, mint olyat, tehát az előző kérdésekben firtatott agressziótól függetlenül közelítem meg, akkor mindkettő jelen van az állatvilágban és a társadalomban egyaránt. Az állatok az altruizmust elsősorban olyanokkal szemben gyakorolják, akikkel génállományuk bizonyos mértékig közös, tehát rokonok, míg az „önzést” azokkal szemben, akikkel ez a kapcsolat nem áll fenn. Kísérletileg igazolták, hogy az altruizmus mértéke állatoknál szoros kapcsolatban áll a rokonság fokával. Ha társadalomfilozófus lennék, ebből messzemenő következtetéseket vonhatnék le arra nézve, hogy a család, nemzetség, törzs, nép, emberiség fennmaradása miképpen függ össze ezzel az irányított altruizmussal, és talán arról is, hogy milyen hatása van a „mind egyek vagyunk” érzésnek az altruizmus általánossá válására, és ez által az emberiség jövőjére. Persze nem vagyok társadalomfilozófus. Ha a kérdést az agresszióra vetítem le, és az önzést az érdekek erőszakkal való érvényesítésével azonosítom, akkor talán egy játékelméleti megközelítést alkalmaznék. Ennek részleteibe most nem mennék bele, de bizonyos játékelméleti modellek szerint sem a kíméletlen erőszak, sem a mindent megengedő békesség nem evolúciósan stabil stratégia. Az általános erőszak felemésztené a közösséget, az általános béke túl nagy előnyhöz juttatná azt, aki agresszióhoz folyamodna, így ez a stratégia túlságosan csábítóvá válna ahhoz, hogy kihagyják. Evolúciósan az agresszív és békés egyedek egy bizonyos arányú vegyüléke tűnik stabilnak, amelyben az agresszívak a közösségnek körülbelül egyötödét tennék ki. Bár ez is meglehetősen spekulatív, úgy tűnik, hogy a gyakorlatban múködik, legalábbis az elvet megfigyelések támogatják. 


\section{M.R.: A kriminológia szerint a látszólag véletlen akaraton alapuló emberi magatartások körében is törvények uralkodnak, csakúgy, mint a fizika vilá- gában.}

H.J.: A véletlent is törvényszerűségek irányítják, erről szól a matematikai statisztika. Visszatérve kérdéséhez: frissen megjelent kriminálpszichológia könyvünkben² szó szerint idéztünk egy szerzőt, aki az ellenkező állásponton volt, mondván, hogy az emberek nem azért bűnöznek, mert gyerekkorukban verték őket, mert szegények, vagy mert drogot fogyasztottak, hanem azért, mert egy adott pillanatban hoztak egy rossz döntést. A viselkedés motivációját tehát a pillanatnyi döntésre redukálta, amely alapulhat félreértésen, pillanatnyi lelkiállapoton, vagy éppen tévedésen, röviden: véletlenszerű. Ebben a szerzőnek tökéletesen igaza van, ha csak az azonnali okra koncentrálunk. Vannak azonban olyan tényezők, amelyek mintegy meghatározzák egy bizonyos fajta döntés valószínűségét. Példával élve: senki nem lesz agresszív pusztán azért, mert pszichostimuláns hatása alatt áll, de ha kialakul egy konfliktushelyzet, nagyobb valószínűséggel nyúl az erőszak stratégiájához, mint drogmentes időszakában. A véletlenből szabály lesz, bár nem egészen úgy, mint a fizikában. A kenyér mindig a vajas felére esik, mert a vaj fajsúlya nagyobb, mint a kenyéré. Az emberi viselkedés esetében pusztán a valószínűsége nagyobb annak, hogy a vajas felére essen, anélkül azonban, hogy ez elkerülhetetlen lenne. Az emberi viselkedés becslésénél ezért van szükségünk matematikai statisztikára.

\section{R.: Kérjük, ezek után foglaljon állást: mit tegyen a jog, mikor büntessen, és mikor legyen elnéző?}

H.J.: Ezt én nem tudom eldönteni, messze fölötte áll annak, amennyit én értek a kérdéshez. Nem vagyok jogász, a jogtörténetben sem vagyok jártas. Egy dolgot viszont elmesélek, mert lehet, hogy ideillik. Itt az egyetemen valakivel beszéltem, aki azt mondta nekem, hogy a bűnt a jog hozza létre, mégpedig azáltal, hogy bizonyos cselekményeket büntetendőnek nyilvánít, más cselekményeket pedig nem. Kíváncsivá tett, ezért az interneten megnéztem Hammurápi törvénykönyvét. A majd négyezer éves törvények egy része ma már nem érvényes, mert a rabszolgákról szólnak, manapság pedig nincsenek rabszolgák. A többit viszont be lehetne tenni bármely mai törvénykönyvbe. Legfeljebb a büntetési tételeket kellene megváltoztatni, mert manapság már senkinek nem vágjuk le a kezét. Ami viszont akkor bűn volt, ma is az. Úgy tűnik, mintha lenne valahol valamilyen természetes jogérzet, ami független az aktuális törvényektől. Ezzel kapcsolatban felidézek egy filmet is a csimpánzokról. Az egész csapat egy fa alatt gyülekezett, és a lehulló diókat törögette fel, hogy hozzájusson a csemegének számító bélhez. Egy kölyök csimpánz megpróbálta eltanulni ennek múvészetét, de mivel nem jutott neki kő, egy fadarabbal próbálkozott, természetesen

Haller József (szerk): A bünözố elme. Budapest, Dialóg Campus, 2020. 
sikertelenül. Ekkor az egyik felnőtt elment diót keresni, és köve őrizetlenül maradt, amit a kölyök kihasznált, és elcsente a követ. Ahogy előbb lopva körülnézett, majd cipelés közben takargatta a követ, ahogy sompolygott, és ahogy egy bokor mögött rejtőzve verte fel új hadiszállását, mind arról árulkodott, hogy tudatában van annak, hogy amit tesz, az lopás. Lehet, hogy a jogot az ember hozza létre, de úgy tűnik, hogy egyes jogszabályok régibbek az embernél.

\section{R.: A kriminálpszichológia miként vélekedik a büntetés helyett alkalma- zott gyógykezelésról, pontosabban a kényszergyógykezelésról?}

H.J.: Nem kétséges, hogy vannak kezelhető problémák, de vannak olyanok is, amelyeknek a tüneteit vissza lehet szorítani anélkül, hogy magát a betegséget meggyógyítanák, és végül vannak olyan állapotok is, amelyeken csak kismértékben és kis eséllyel lehet segíteni. Vannak továbbá mentális vagy neurológiai állapotok, amelyeken - ma legalábbis - egyáltalán nem lehet javítani. Mind a négy kategóriában vannak olyan mentális zavarok, amelyek megnövelik a bűnözés kockázatát. Ha a bűnözés visszaszorításának oldaláról fogom fel, akkor a problémák orvosi kezelése egy esély, ami közelebb visz a célhoz. Ha a bűnöző oldaláról nézem, akkor megint egy esélyt látok, ezúttal a normálisabb élethez. Mind a két oldalnak jobb, ha az okot szüntetjük meg, mint ha simán megtorolunk valamit. Ehhez persze az kell, hogy a zavar vagy betegség fennálljon, valóban megnövelje a bűntettek elkövetésének kockázatát, és az állapot kezelhető legyen. Vannak olyan esetek is, amikor a bűntett visszaszorítása érdekében ártanak az elkövetőnek, anélkül, hogy bármilyen módon segítenének rajta. Az úgynevezett vegyi kasztrációról, más néven antiandrogén terápiáról beszélek. A cél a szexuális, köztük a pedofil bűncselekmények elkövetésének - lényegében a bűnismétlésnek - a kizárása. A jogos-nem jogos kérdéssel nem foglalkozom, mert nem kompetenciám. Összességében azonban a kezelésekben egyfajta reményt és ígéretet látok, ugyanakkor egyfajta morális kötelességet is. Ha valaki eltöri a lábát, gipszbe teszik, függetlenül attól, hogy az illető bűnöző, vagy sem. Miért ne tennénk ugyanezt mentális zavarok esetében is, különösen akkor, ha ez a börtönön belüli és kívüli bưntetteket is visszaszorítja?

\section{R.: Müködik ez a vegyi kasztrálás valahol?}

H.J.: Én tíz európai - többnyire EU - országról tudok, ahol alkalmazzák, és nagyjából hasonló számú országról más kontinenseken. Többek között az Egyesült Államokban is végrehajtanak ilyen beavatkozást. A kezelések sikeresek. Egyes országokban csak kivételes esetekben alkalmazzák, máshol az elkövető választhat, hogy kezelik vagy börtönbe kerül, ismét máshol bírósági ítélettel lehet valakit vegyi kasztrálásra kényszeríteni. Itt a bűnöző legfeljebb börtönévektől szabadulhat meg, de megfosztják életének egy fontos összetevőjétől - a szexualitástól - és a kezeléseknek eléggé súlyos mellékhatásai vannak. A potenciáis áldozatok viszont megszabadulnak egy fenyegetéstől. 


\section{R.: De ez a jövöre vonatkozik, a múltat pedig akkor elfelejtik?}

H.J.: Azt hiszem, országonként más és más a helyzet, bár nem néztem utána nagyjából húsz ország törvénykönyvében. Tudok viszont olyan országról, ahol az antiandrogén terápia valódi alternatíva, vagyis a megtorlás kikerül a képletből. Ahogy fogalmaztál: a múltat néhány helyen valóban elfelejtik, mert a vegyi kasztráció megszünteti a veszélyt.

\section{M.R.: A szexuális rendellenes magatartások egyike az úgynevezett vérfer- tőzés, az egyenes ági rokonok szexualitása. Az emberek többsége nem érez szexuális vágyat a leszármazottja vagy a testvére iránt. Ez biológiai vagy pedig társadalmi hatásnak tudható be?}

H.J.: Nem merném azt mondani, hogy ez egy természeti törvényszerűség, de megfigyelték, hogy az állatok életmódja, életciklusa úgy alakult ki, hogy a lehető legkisebb legyen az esélye annak, hogy rokonok egymással szexuális kapcsolatba kerüljenek. A tipikus példa az, hogy a domináns hím a fiatal hímeket elüldözi a csoportból, így azok kénytelenek más csoportokban, nem rokonok között párt találni maguknak. Talán ez a biológiai háttér magyarázza a társadalmi tabu mára legalizált formáit. Ezzel együtt, vérfertőző szexuális kapcsolat az állatvilágban és a társadalomban előfordul néha. Például a fáraók gyakran vették el a testvérhúgukat feleségül, és egyes természeti népeknél a szülő és gyerek közötti szexuális kapcsolat része a felnőtté avatási szertartásnak. A rokoni kapcsolatnak valóban vannak genetikai kockázatai, ezért a természet mintegy óvintézkedéseket tesz ellene, de előfordul, és a negatív következmények nem azonnaliak, és még csak nem is kötelezőek. Vannak életképes laboratóriumi állattörzsek, amelyeket testvérek több generációs párosításával hoztak létre, hogy csökkentsék a genetikai variabilitást.

\section{R.: Fontos, hogy közterületi munkában, amikor intézkedik a rendőr, képes legyen felismerni a rendellenes magatartás mögötti biológiai hátteret, pél- dául az értelmi fogyatékosságot?}

H.J.: Én a biológiai-pszichológiai-pszichiátriai hátteret nem szúkíteném le az értelmi akadályozottságra. Ezt egyrészt könnyú felismerni, másrészt nem is a legfontosabb eleme a problémakörnek. Egyébként igen, szükséges ismereteket szerezni a bűntettek biológiai hátteréről, mert ezt nem lehet elválasztani a pszichológiától, illetve a pszichiátriától. A három egységes egészet alkot. Ráadásul vannak bűnözői viselkedések, amelyek magyarázatában egyértelmúen a biológia viszi a prímet. A pszichózis, drogfüggés és néhány más bűnözéshez kapcsolódó zavar egyértelműen az agy produktuma. A szakirodalomban ezeket már évtizedek óta úgy hívják, hogy „brain disease”, vagyis az „agy betegségei”. Tévúton jár, aki azt hiszi, hogy pusztán pszichológiai megközelítésben tárgyalhatók az ilyen zavarok. 


\section{R.: De mit szólnak ehhez a rendészeti hallgatók, akik mégiscsak jogalkal- mazói szerepet fognak betölteni? Fogadják ezeket a gondolatokat, hogyan jelzik vissza, hogy érdekli őket vagy fontosnak tartják?}

H.J.: Oktatóként azt tapasztalom, hogy többségük elkötelezetten foglalkozik tárgyaimmal, és látványosan jól teljesít az ismeret-ellenőrzések során. Sokszor kimondottan büszke vagyok rájuk, mert olyan feladatokat is jól oldanak meg, amelyek egy szakértőnek is kihívást jelentenének. Egyébként megértem álláspontodat: a rendőr valóban jogalkalmazó. Ugyanakkor szakmája révén emberekkel foglalkozik, ráadásul olyan emberekkel, akiknek az átlagnál sokkal több problémája van. Ezzel a hallgatók többsége a jelek szerint tisztában van, és ennek megfelelően veszi az adást.

\section{R.: Talán azt is fel kell ismernie, hogy orvost kell hívni, és ha elmulasztja, még büntetést is kaphat érte.}

H.J.: Igen, ezért felhívom a hallgatók figyelmét azokra a helyzetekre, amelyekben nem boldogulnak orvos nélkül. Egy drog hatása alatt álló személyt például megfigyelés alatt kell tartani a fogdában, mert nem tudni, hogy mennyi drogot fogyasztott és mikor. Lehet, hogy éppen kilábal az állapotából, de lehet, hogy csak ez után tetőződik a drog hatása, és életveszélybe kerülhet. Nem akkor kell orvost hívni, amikor a fogvatartott már a földön fekszik, és levegő után kapkod. Számtalan ilyen helyzet van, ezek a tárgyak fontos elemét képezik.

\section{M.R.: Minden leendő rendőrt meg tud szólítani?}

H.J.: A „minden” nyilván túlzás. Én sem szerettem minden tárgyat az egyetemen, és ezzel a mai hallgatók sincsenek másképp. A többséget azonban igen, megszólítják tantárgyaim. Egy hallgató néhány évvel ezelőtt azt írta, hogy azért szeretné megismerni a bünözóket, hogy ha találkozik velük, ne tépje le a fejüket. Ez, hogy is mondjam, kissé eredeti megfogalmazás, de éreztem a jó szándékot mögötte. Szeretné érteni a bűnözőket, hogy ne bántsa őket feleslegesen. A hallgatók jelentős része ugyanilyen. Nem is egyszerűen a törvény betűje szerint, hanem erkölcsösen is akar múködni a szolgálata során. Ez pedig nem lehetséges anélkül, hogy ismerné azokat, akikkel dolgozik - szakmailag is és emberileg is.

\section{R.: Nos, kedves professzor úr, ön hogyan határozná meg kutatói és oktatói profilját?}

H.J.: Viselkedés-neurobiológus vagyok, de az elmúlt négy évtizedben kizárólag olyan kérdésekkel foglalkoztam, amelyek rendészetileg fontosak. Agresszió, drog, stressz, poszttraumásstressz-zavar - ezek voltak kutatói pályám legfontosabb témái, és ennek oktatóként hasznát veszem. Úgy gondolom, hogy annak is hasznát veszem, 
hogy kutatóként mindig a felderíthető tények érdekeltek, és sokkal kevésbé az elméletek. Az elmélet számomra csak akkor érdekes, ha tényeket magyaráz meg, nem akkor, amikor tényeket kreál, vagy ténynek állít be feltételezéseket. Úgy alakult egyébként, hogy kutatói tevékenységem mintegy rákényszerített a multidiszciplináris megközelítésekre, ami a kriminálpszichológia oktatásánál is nagyon fontos. Valahogy úgy érzem, hogy a kutatói és oktatói tevékenységem egységes egész - mindkettőben a megismerhető tények és a többszempontú megközelítés játssza a főszerepet, ráadásul a kutatott és oktatott témák jelentős mértékben átfednek. Persze volt mit hozzátanulnom ahhoz, amit már eleve tudtam, de gondolom ezzel mindenki így van. Senki sem lehet „mélyszakértő” minden témában, amit egy tág tudományág lefed. Elég, ha néhányban az, és a többit nem veszi félvállról.

\section{M.R.: És miképpen sikerült betagozódni a rendészeti oktatásba?}

H.J.: A rendészettudományba fokozatosan sodródtam bele, egy ideig anélkül, hogy észrevettem volna. Hollandiai kutatásaim során, még a '90-es években született egy eredményünk, amit a kurrens neurobiológiai ismeretek alapján nem tudtunk megmagyarázni, és csak néhány hetes búvárkodás után sikerült fellelni azt a rendészettudományi kutatássorozatot, amely értelmet adott annak a bizonyos értelemben bizarr kutatási eredménynek. Ettől annyira megdöbbentem, hogy félretettem neurobiológusi „önérzetemet”, és évekig egyebet sem tettem, mint a bűnözés szakirodalmát olvasgattam, majd az olvasottakat viselkedés-neurobiológusi munkám során kamatoztattam. Később kutatási együttmüködést építettünk ki Farkas István tábornok úrral, aki a rendőrség Nemzetközi Oktatási Központjának, a NOK-nak az igazgatója. Így amikor felvetették a lehetőségét annak, hogy a karra jöhetnék kutatni és oktatni, nem sokat gondolkodtam rajta. Csak halkan mondom: kissé már untam is modelljeinket, csábító volt, hogy azt tanulmányozhatom, amit korábban modellezni igyekeztünk, az oktatás pedig bónusz volt. Mindig oktattam, akkor is, amikor kutatóként ez számomra nem volt kötelező.

\section{R.: A rendészettudomány területén nagyon kevés a külföldi kapcsolat.}

H.J.: Igaza is van, meg nem is. A kar tudatosan és sikerrel építi ki nemzetközi kapcsolatait, ezen a téren jobban áll, mint eredetileg gondoltam volna. Ugyanakkor tény, hogy a nemzetközi tudományos porondon rosszabbul teljesít, mint amire képes lenne. Sok a tennivaló, amit a magam kisléptékű eszközeivel, elsősorban a doktoranduszaim támogatásával igyekszem is előmozdítani. Fontos felkerülni a nemzetközi tudományos térképre, és ott is maradni. Ez vonatkozik a saját doktoranduszaimra és azokra a generációkra, akiket már ők fognak kinevelni. A kar jelentős része már megérett arra, hogy ne pusztán átvegye a külföldi jó gyakorlatokat, hanem kutatásai révén ilyen jó gyakorlatokat maga hozzon létre. Ezt a képességet kell készséggé fejleszteni. 


\section{M.R.: És a vége felé az obligát kérdés: van-e a kérdésekre adott válaszokon túli mondanivalója?}

H.J.: Igen, ez néhány bevett kihallgatási technika szokásos utolsó kérdése. „Képzeljék magukat a helyembe, mit kérdeznének még?” - ezt a záró kérdést oktatták az FBI kihallgatótisztjei azon a kurzusukon, amelyen részt vettem. Nos, nem ragadt bennem mondanivaló. Örömteli volt számomra ez a beszélgetés. 